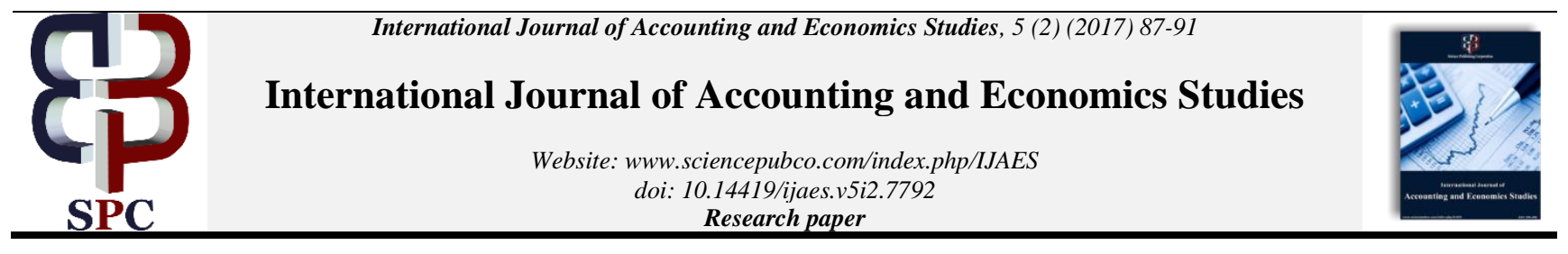

\title{
Stock index manipulation around election announcements: evidence from Pakistan stock exchange
}

\author{
Shahbaz Khan ${ }^{1 *}$, Razzi Abbas Jafri ${ }^{2}$, Nida Baig ${ }^{3}$, Muhammad Shaique ${ }^{4}$, Muhammad Usman ${ }^{1}$ \\ ${ }^{1}$ School of Finance, Zhongnan University of Economics and Law, Wuhan, P.R.China \\ ${ }^{2}$ National Bank of Pakistan \\ ${ }^{3}$ School of Public Administration, Huazhong University of Science and Technology, Wuhan, P.R.China \\ ${ }^{4}$ School of Accounting, Zhongnan University of Economics and Law, Wuhan, P.R.China \\ *Corresponding AuthorE-mail: shahbaz.khans@yahoo.com
}

\begin{abstract}
The purpose of this study is to find out the impact of political general elections of Pakistan on KSE-100 index. We employed Event study methodology on closing prices of KSE-100 index over the time period January, 1998 to May, 2013. During our sample period, 3 events of political general Elections occurred i.e., Event1 in 2002, Event2 in 2008, and recently Event 3 in 2013 . We construct an Event window of 11 days consisting of 5 pre-event days, 1 on-event day, and 5 post-event days. Results of this study show that Events 1 -and 2 put significant negative impact on stock returns, while Event 3 demonstrates a significant positive impact on stock returns. This study also revealed the pre -and post-event comparison for all of the three events and, suggested that as soon as the political situation of the country changes, behavior of investors towards political general election also changes. Manipulation in stock index has always been remained an inconclusive phenomenon for investors and policy makers. So, further evidence on an individual country level might suggest fruitful guidelines to both investors and policy makers.
\end{abstract}

Keywords: Political Elections; Pakistan Stock Exchange; Stock Returns; Market Efficiency; Event Study.

\section{Introduction}

Stock market does behave in an uncertain, anonymous manner. It is really hard to predict the movement of stock market but still stock market is considered to be the most important part of any country's economy. No one can deny the importance of stock market. Due to technological advancement in the communication sector, the flow of information is getting fast and faster day by day. Any news or information in the country travels fast and acknowledge masses of people quickly. Today is the era of information technology; information brings shocks in the capital as well as in the stock market. Both markets are flexible enough to absorb the effects brought up by different type of news or information like terrorism, political instability etc.

Hypothesis of efficient market states that investor's reaction is very divergent when they are expecting alternative trends in the stock market. However, it creates a kind of market environment where in a long run; single investor cannot exploit the market. In other words, hypothesis of efficient market creates the perfect competition in the market. This hypothesis is based on the random walk theory and fundamental reason behind this is that the available information in the market has no connection with stock price changes. So, to estimate a macroeconomic model it is better to incorporate financial market efficiency because without considering the efficiency of market the estimation model produces misleading results (Mishkin, 1982).

According to the efficient market hypothesis by Fama (1965), market has been classified into three types in terms of efficiency: strong form, semi strong form and weak form efficient market. The market is perfectly efficient when stock price immediately captures the available relevant information in the market. Furthermore, in an efficient market the effect of an event is considered significant it the prices show non-random movement immediately after the event. So we can measure the level of efficiency by checking the type of information and speed of market reaction against new or uncertain information. However, event study has a property that it measures the impact of specific information on stock prices.

Elections are the peak time when the economy of any country likely to be affected by the political circumstances. Political situations have always been a solid reason for the boost or decline of any economy (e.g., see studies by Hibbs, 1977; Alesina et al., 1997). Pakistan could be considered as one of that episodic-democratic countries which are facing continuous upheavals and socio-political disruptions since their inception. In Pakistan, political situations are really uncertain, which make the business position mostly unstable. Decline of points in KSE-100 index due to any political change is a normal behavior for stock exchange market in Pakistan. Stock market in Pakistan shows rough patch during the last 15 years. It is likely to be considered as unreliable place for investment. Political elections in developing countries, like Pakistan, do bring many political changes over the period of time. These changes do influence the stock exchange of the country, whether in a positive manner or in negative manner.

In Pakistani financial markets, weak form of efficiency prevails. The information prevailing in the country is easily reflected in the stock market. Political elections and any news regarding them, prevailing in the country may influence the stock market of the country. Therefore, it is required to pay attention towards the factors that may control the effects of political change on stock market. This 
study attempts to study the relationship of political elections and financial markets. In general, it can be precise as whether political elections do make any influence of Pakistan Stock Exchange or not? Remainder of the paper is organized as follows: section 2 presents literature review and hypotheses development, section 3 lays out detail methodology, section 4 discusses the results as obtained from data analysis, and finally section 5 concludes the overall paper with the help of policy implications, suggestions and recommendations for future research.

\section{Brief literature review}

There is ample empirical evidence on the effect of political elections and opinion polls on stock prices in context of developed nations. Manning (1989), for example, focused on political uncertainty and, checked if its effect on stock prices was stable and persistence after the elections or not. He concluded that shares price of British telecom responded strongly to the election of 11 June 1987. Floros (2008) conducted a study in Greece to analyze the effect of political elections on Athens stock exchange (ASE). He used daily closing prices of ASE index for the period of 1996-2002. Applying pre -and post -election examination, they used ordinary least square (OLS) models and, found that stock market performed negatively in pre-election stage and, there was a considerable increase of index at post-election stage in the long run. It was because of the fact that due to the uncertainty of results market becomes more nervous before the elections and resultantly there comes fewer numbers of transactions at that stage which move overall index towards downside. While after the elections market is steady, so there is expectation of somehow stable economic and monetary policy and, this thing pulls the stock market to show increasing trend.

Relationship between election polls and Toronto stock exchange was studied by Brander (1989). He focused during the campaign period of 1988 Canadian election and used the "poll influence" hypothesis. (Weather the polls influence the stock market). Results supported polls hypothesis and he concluded the polls significantly affect the stock prices.

Shum (1996) examined the Canadian stock market one day before the elections (1992 constitutional referendum) and checked weather investors were concerned with election activity on the day before elections or not. He found most of the investors were inclined to have "Yes" vote during referendum. And they were highly concerned about that. He concluded that in the short run this effect persists due to public concerns but this election shock decreases gradually and come to its original position in the long run. Similarly, Leblang and Mukherjee (2005) found that US stock market increased its volatility in 2000 presidential elections. He used GARCH model to test the mixture of distribution hypothesis. Fong and Koh, (2002) worked on Hong Kong stock market. They used a large data consist of weekly returns of hang seng index (HSI) from January 1970 to April 1998 to investigate the impact of political risk on stock market volatility. Using Markov switching model, they found that regime shift increases the volatility of market. From early 1980 's, there were 5 major political events and results confirmed that in each of these periods the Hong Kong stock market switched to a high volatile state. They also found that bad news (negative shocks) is the reason of high volatility while good news is associated with low volatility. In high volatility regime evidence of a leverage effect was also found.

Nippani and Arize (2005) indicated that stock market performance was not the same in pre-election comparison period. They examined the U.S presidential election of 2000 on performance of stock market for the period of My 19, 2000 to December 14, 2000. Study used simple t-test and regression analysis on three stock markets which are widely followed by the investors; Standard and poor's 500, Dow Jones industrial average and the NASDAQ composite Index. The results suggested that market performed negatively on pre-election stage and then boosted up after the election. They also suggested that most of the reaction of market was seen on the first four trading days after the elections.
Election process can be seen at its peak on last night. Investors keep a close eye on happenings to get accurate and relevant news which are going to put their effect in long term. A huge activity on this night makes market more mobilize. To examine this fact, Steeley (2003) checked the market response to election news events during that night. He found the evidence that the UK financial markets respond to evolving pattern of results on one night before elections. Huber and Kirchler (2011) checked the contributions of companies before an election and their stock market performance after US presidential elections from 1992-2004. They concluded that companies outperformed the stock market which provided higher percentage of contribution to eventual winner. Similarly, Pepinsky (2007) pointed out that political parties reward their supporters and punish their opponents with the use of fiscal policy. A time series analysis of fiscal expenditure of Malaysia is done from 1967 to 1997 to show how systematically ruling party create favors for its supporters in non-democratic regime.

Jones and Banning (2009) observed no such significant difference in monthly stock returns. They also suggested that it is not appropriate to invest using a rule of thumb because investing decision is not as simple as just based on which political party the president belongs to. They revealed that it's not political party to which stock market favors, rather its macroeconomic factors which are associated to those parties. For example higher GDP growth is correlated with Democratic Party and lower inflation is correlated with Republican Party. Now stock market may favor one of those macroeconomic factors and it will seem like favoring one of the political parties

Huang et al., (2011) enlightened the fact that during political crises corporate governance and performance of an individual firm are also the major component to stock market volatility. From Taiwan presidential election 2004 they triggered that better corporate governance and performance decrease the volatility of stock market during such political crises. Investor's uncertainty created during election can be minimized by attaining confidence of stability in firm's performance.

Having a look on above literature it can be seen that stock market behaves differently in different countries depending upon their local conditions and circumstances. Some countries are highly concerned about political activity and others or not. There is no such universal barometer to check weather elections have any impact on stock market. Results of one country's election cannot be applied over the other. Moreover, there is not a single trend being followed in all over the world which shows there is positive or negative impact of elections on stock market. To suggest some further suggestions to this issue, a study is needed to check this impact on Karachi stock exchange. It will make us well aware of our local market and its response to political elections. A lot of work in this area has been done in developed countries consisting upon different dimensions, but developing countries are lagging behind which increases the importance of our study. In his most recent work, Khan et al., (2017) also suggested to check the impact of political elections on Pakistan stock exchange. That's why this study is going to fill the gap and, may contribute in the existing literature.

\section{Methodology}

We gather data from yahoo finance which seems to be a very reliable source of financial data. We include 15 years data from January 1 st, 1998 to May 31st, 2013. We calculate daily stock by using daily closing prices of KSE- 100 index. We could include only 5 days a week because there is no trading on KSE-100 index on Saturdays and Sundays. Moreover, the missing values of data were obtained through using the formula of interpolation because E-views does not support the missing values of data. In this way 4021 observations were obtained for our study.

Political elections in Pakistan also occur after every 5 years. So this study covers 3 events of political elections in Pakistan during our sample period. Event 1 occurred on October 10, 2002, event 2 occurred on February 18, 2008, and event 3 occurred on May 11, 2013 
Mackinlay (1997) suggested that event methodology is the most suitable method to get the impact of an event. We construct an event window of 11 days for pre -and post-election analysis. This breakdown can be seen like this:

- Event-day consists of 1 day

- Pre-event consists of 5 day

- Post-event consists of 5 days

For their symbolic representation event day takes the value of zero; pre-election days takes the value starting from (t-1) to (t-5); and post-event days takes the value starting $(t+1)$ to $(1+5)$. In this way, we got 3 event windows for each of the event consisting of 11 days as follows:

- $\quad$ Event Window1- October 3,2002-to- October17,2002

- $\quad$ Event Window2-February11,2008-to-February25,2008

- $\quad$ Event Window3- May 6,2013-to-May, 202013

We calculate daily stock returns by using daily closing prices of KSE-100 index and, next abnormal returns are calculated through forecasting. To find abnormal returns we forecast the values for each event window. For that purpose we create an estimation window for each of the event consisting of 250 days before the event window. This estimation window includes the effect of whole year in forecasted values which makes our results more reliable.

- Estimation window1 refers to May 21, 2012 to May 3, 2013

- Estimation window2 refers to February 26, 2011 to February 8, 2008

- $\quad$ Estimation window3 refers to October 18, 2001 to October 2, 2002

We apply $\operatorname{ARCH}(2,1)$ for event window1, and 2, while ARCH $(2$, 0 ) for event window 3 to get the forecasted returns. Mathematically, we calculate daily stock returns as follows:

$$
R_{t}=\ln \left(P_{t} / P_{t-1}\right)
$$

Where, $\boldsymbol{R}_{\boldsymbol{t}}$ represents stock return for a day ' $\mathrm{t}$ ' of KSE-100 index, $\boldsymbol{P}_{\boldsymbol{t}}$ is closing price for a day ' $\mathrm{t}$ ' of KSE-100 index and $\boldsymbol{P}_{\boldsymbol{t}-\mathbf{1}}$ is closing price of KSE-100 index for a day ' $t-1$ '. After that, we calculate abnormal returns by taking the difference of actual returns and average returns:

$$
A R_{t}=R_{t}-A v g R_{\text {est win }}
$$

Where, $\boldsymbol{A} \boldsymbol{R}_{\boldsymbol{t}}$ represents abnormal return for a day 't' of KSE-100 index and $\boldsymbol{A} \boldsymbol{v} \boldsymbol{g} \boldsymbol{R}_{\text {est win }}$ is average return of an estimation window preceding 250 days to day ' $t$ '. Next, average abnormal returns $\left(\boldsymbol{A A R} \boldsymbol{R}_{\boldsymbol{t}}\right)$ are estimated as:

$$
A A R_{t}=\frac{1}{N} \sum_{i=1}^{n} A R_{t}
$$

Then, cumulative abnormal returns $\left(\boldsymbol{C A} \boldsymbol{R}_{\boldsymbol{t}}\right)$ are predicted as follows:

$$
C A R_{t}=A R_{t}+C A R_{t-1}
$$

Next, to check the statistical significance of $\boldsymbol{C} \boldsymbol{A} \boldsymbol{R}_{\boldsymbol{t}}$, we calculate Tvalues as follows:

$$
T=A C A R_{t} / S D_{\text {estwin }}
$$

Where, $\boldsymbol{A} \boldsymbol{C A} \boldsymbol{R}_{\boldsymbol{t}}$ is average of $\boldsymbol{C A} \boldsymbol{R}_{\boldsymbol{t}}$. Analytically, we may write our equation as:

$$
\operatorname{ACAR}_{t}=\frac{1}{N} \sum_{i=1}^{n} C_{A} A R_{t}
$$

If the test statistic's values are greater than 1.96 , then the value of abnormal returns would be significant at $95 \%$ level.

\section{Results and discussion}

We would discuss each of the events one by one as follows:

(Event 1). We take elections 2002 as Event 1 that exactly occurred on October 10, 2002. Table 1 reports that it creates a negative impact on stock market in both pre -and post event stages. Pre-event results are somehow better and show the downward movement of stock prices up to $1.183 \%$. At pre-event stage each of the days showed the same response except $\mathrm{t}-3$ where stock prices increased slightly and market showed a positive response. This thing saved the, market from a huge negative shock on pre event stage. Even on the Election Day there was a negative impact on KSE-100 index and stock prices decreased by 6.16 . There was not a single day which can create a positive impact after the election creating $4.4 \%$ downfall in stock prices at post-event stage. From another point of view these results are not as bad as they look apparently. because there is a huge negative shock on election day ( $t$ ) which never allowed the market to come out of it afterwards. And this effect persists every day after the election. Ignoring event day, Table 1 shows decrease of $4.44 \%$ in stock prices after the election and $1.13 \%$ before the election. Pre-event stage is somewhat better than post-event stage because before the election there is some kind of uncertainty regarding the outcomes of election. Investors keep a keen eye over the happenings to save their personal interests. But at this post event stage this uncertainty does not prevails any more. T. Value refers to the significance of impact created by the election 2002.

Specifically, discussing about Pakistani scenario, election of 2002 was conducted under military umbrella. There was no democracy at that time in the country and country was facing martial law before the election. General Pervaiz Musharraf was the chief martial law administrator at that time and that was not a political figure in the country. Keeping this scenario in mind, Table1 shows compatibility in our market to greater extent. According to efficient market hypothesis market behaviour caters all the information arising at that time. There was a general perception that these elections will not produce different results and policies will not be changed any ways. For that reason market remain somehow stable at pre-event stage. A slight decrease of $1.13 \%$ was observed. And after the elections, a new political party PML-Q came into power. It was relatively a new political party on political map of Pakistan. Investors were not well aware of their policies and it became the reason of negative shock of $6.6 \%$. This shock kept on decreasing after wards in post-event stage. But it created overall significantly negative impact.

(Event2)- Election of 2008 is referred as Event 2 in this study which is exactly occurred on February 18, 2008. Table 2 shows the abnormal returns for event 2 in both pre -and post event stages of event. It shows somehow better results as compared to event 1 . But stock prices are still negative in this event which creates overall negative impact of elections on stock prices. Table 2 shows that event day (t) did not create any shock as the abnormal returns have a slight decrease of $0.67 \%$ on that day which is not a significant one. In pre event stage stock prices decreases up to $2.36 \%$. Only day (t-2) got a slight increase in stock prices while all other days of pre-election window had a negative impact of elections. When we have a look on post-event window the story is not much different. There is negative impact as well but this is an ignorable impact being $-0.018 \%$. In this stage of event $(t+2)$ and $(t+3)$ got an increase in stock prices while all other days showed a negative impact.

Contrary to Event 1, it is also observed from Table 2 that here postevent results are better than pre-event results. Keeping these results in mind, when we observe the political situation of Pakistan in 2008 they look compatible in this economy. In election of 2008, democratic situation of country was pretty good as compared to previous elections. Unlike previous election of 2002, where competition was not substantial, president of Pakistan was an army chief as well and was the supreme power in the country, and main leaders of other parties (Benazir Bhutto and Mian Nawaz Sharif) were out from election campaign; democratic situation was relatively better in 2008. These things gained the confidence of investors to some extent and in this way effect on stock market was not as bad as it was in previous elections. 
Table 1: CAARS around Elections 2002

\begin{tabular}{|c|c|c|c|c|}
\hline $\begin{array}{l}\text { Time } \\
\text { Period }\end{array}$ & $\begin{array}{l}\text { Actual Re- } \\
\text { turns }\end{array}$ & $\begin{array}{l}\text { Forecasted } \\
\text { Returns }\end{array}$ & $\begin{array}{l}\text { Abnormal } \\
\text { Returns }\end{array}$ & CAAR \\
\hline$t-5$ & -0.0057 & 0.00608 & -0.0118 & -0.0118 \\
\hline$t-4$ & 0.0055 & 0.00226 & 0.0033 & -0.0085 \\
\hline$t-3$ & 0.0110 & 0.00083 & 0.0101 & 0.0016 \\
\hline$t-2$ & -0.0467 & 0.00040 & -0.0471 & -0.0455 \\
\hline \multirow[t]{2}{*}{$t-1$} & -0.0012 & 0.00024 & -0.0015 & -0.0470 \\
\hline & & & & -0.0111 \\
\hline $\mathrm{T}$ & -0.0144 & 0.00017 & -0.0146 & -0.0616 \\
\hline$t+1$ & -0.0275 & 0.00015 & -0.0277 & -0.0893 \\
\hline$t+2$ & 0.0207 & 0.00014 & 0.0205 & -0.0688 \\
\hline$t+3$ & -0.0259 & 0.00014 & -0.0261 & -0.0948 \\
\hline$t+4$ & -0.0037 & 0.00014 & -0.0038 & -0.0987 \\
\hline \multirow[t]{5}{*}{$t+5$} & 0.0062 & 0.00014 & 0.0060 & -0.0927 \\
\hline & & & & -0.4442 \\
\hline & & S.D & & 0.0383 \\
\hline & & T. Value & & -2.4148 \\
\hline & & Significance & & Yes \\
\hline
\end{tabular}

Source: Author's own computation in MS-Excel

Table 2: CAARS around Elections 2008

\begin{tabular}{|c|c|c|c|c|}
\hline $\begin{array}{l}\text { Time } \\
\text { Period }\end{array}$ & $\begin{array}{l}\text { Actual Re- } \\
\text { turns }\end{array}$ & $\begin{array}{l}\text { Forecasted } \\
\text { Returns }\end{array}$ & $\begin{array}{l}\text { Abnormal } \\
\text { returns }\end{array}$ & CAAR \\
\hline$t-5$ & -0.0009 & 0.00191 & -0.0028 & -0.0028 \\
\hline$t-4$ & -0.0022 & 0.00292 & -0.0052 & -0.0079 \\
\hline$t-3$ & -0.0005 & 0.00304 & -0.0036 & -0.0036 \\
\hline$t-2$ & 0.0048 & 0.00306 & 0.0018 & -0.0018 \\
\hline \multirow[t]{2}{*}{$\mathrm{t}-1$} & -0.0045 & 0.00306 & -0.0076 & -0.0076 \\
\hline & & & & -0.0236 \\
\hline $\mathrm{T}$ & -0.0037 & 0.00306 & -0.0067 & -0.0143 \\
\hline$t+1$ & -0.0028 & 0.00306 & -0.0059 & -0.0059 \\
\hline$t+2$ & 0.011 & 0.00306 & 0.0080 & 0.0021 \\
\hline$t+3$ & 0.0085 & 0.00306 & 0.0054 & 0.0054 \\
\hline$t+4$ & 0.0016 & 0.00306 & -0.0015 & 0.0039 \\
\hline \multirow[t]{5}{*}{$t+5$} & -0.0042 & 0.00306 & -0.0073 & -0.0073 \\
\hline & & & & -0.0018 \\
\hline & & S.D & & 0.0091 \\
\hline & & T. Value & & -2.0156 \\
\hline & & Significance & & Yes \\
\hline
\end{tabular}

Source: Author's own computation in MS-Excel

Table 3: CAARS around Elections 2013

\begin{tabular}{|c|c|c|c|c|}
\hline $\begin{array}{l}\text { Time } \\
\text { Period }\end{array}$ & $\begin{array}{l}\text { Actual Re- } \\
\text { turns }\end{array}$ & $\begin{array}{l}\text { Forecasted } \\
\text { Returns }\end{array}$ & $\begin{array}{l}\text { Abnormal } \\
\text { Returns }\end{array}$ & CAAR \\
\hline$t-5$ & 0.0016 & -0.00546 & 0.0070 & 0.0070 \\
\hline $\mathrm{t}-4$ & 0.0003 & 0.00347 & -0.0032 & 0.0038 \\
\hline$t-3$ & 0.0108 & -0.00168 & 0.0125 & 0.0125 \\
\hline$t-2$ & 0.0097 & 0.00133 & 0.0084 & 0.0209 \\
\hline \multirow[t]{2}{*}{$t-1$} & 0.0129 & -0.00042 & 0.0133 & 0.0133 \\
\hline & & & & 0.0575 \\
\hline $\mathrm{T}$ & 0.0164 & 0.000576 & 0.0158 & 0.0158 \\
\hline$t+1$ & 0.0113 & $2.9 \mathrm{E}-060$ & 0.0113 & 0.0113 \\
\hline$t+2$ & 0.0045 & 0.000334 & 0.0042 & 0.0042 \\
\hline$t+3$ & -0.0073 & 0.000143 & -0.0075 & -0.0075 \\
\hline$t+4$ & 0.0059 & 0.000253 & 0.0056 & 0.0056 \\
\hline \multirow[t]{5}{*}{$\mathrm{t}+5$} & 0.0134 & 0.000189 & 0.0132 & 0.0132 \\
\hline & & & & 0.0268 \\
\hline & & S.D & & 0.0275 \\
\hline & & T. Value & & 2.9257 \\
\hline & & Significance & & Yes \\
\hline
\end{tabular}

(Event 3).Last event of the study i.e., Event 3 was the elections of 2013 which exactly occurred on May 11, 2011. Table 3 reports the results for event 3 i.e., most recent elections for pre -and post-election windows, which clearly indicates the positive impact of elections. In pre-event stage increase in stock return due to election was observed up to $5.75 \%$. There was not a single day which had a negative impact. Those all positive impacts made the overall increase in pre event stage. Event day showed the increase of $1.58 \%$. Postevent stage once again had a positive impact of $2.68 \%$. Table 3 also showed that results of pre-event stage are relatively better than postevent stage. It was because of the reason that $(t+3)$ was the only day in post-event stage which showed negative impact and due to this fact, overall post-event window could not perform better than pre- event window. Throughout the event window of 11 days we can clearly observe a positive impact of elections on stock prices.

To discuss these results, we have to take an overview of political situation of Pakistan in 2013. Current situation referred to a complete democratic structure and three major political parties were the contestants in these elections in Pakistan. A tough competition was observed here where youth participation was at its peak. From investors' point of view involvement of people at a big level in political activity was a positive sign. This thing gained the confidence of investors and triggered them to increase the volume of transaction during the election. There is a general perception that policies of PML-N are highly suitable for investment point of view. After the election PML-N came into the government for the $3^{\text {rd }}$ time which was a big boost for investors. Because investors are always been the beneficiaries in previous eras of PML-N. This was another reason why stock market performed better in recent election of 2013

\section{Conclusion}

This study examined the impact of general political elections on KSE-100 index returns particularly in the context of Pakistan. It is necessary to mention that this study focused on election shock specifically. It does not reflect the overall position of economy. Because the election shock created during an event eventually vanishes after sometime and stock market returns back to its normal position.

In event 1 due to the strict policies of Marshal Law the investors hesitate to invest in the stock market, they did not respond positively to the event, secondly any effective election campaign had not been observed by any party because most of the party leaders were out of the country. It makes the situation worst as we observed in the table 1 . Therefore there was a negative election shock on stock market. During 2008, the stock market was performing well and it was expected that during elections it will create a positive shock. But few days before the event, the Death of Benazir Bhutto (chairperson of Pakistan Peoples Party) in a terrorist attack created concerns for investors.

Whereas, in event 3 (2013), the situation is entirely different. For the first time in the history of Pakistan, the national assembly has successfully completed their tenure. The election campaigns and election proceedings collected great involvement of people masses. There was a complete political shift from dictatorship towards democracy in this election. The political stability had made the investor attract towards the stock market of Pakistan. Intensive competition among political parties and formation of investor's friendly government i.e., Pakistan Muslim League (Nawaz) was another reason of positive shock on stock market. It is reported that right after the election event, the stock market boost up from 16000 points to 22000 points. This is a good indictor towards the boost of Pakistani economy.

After evaluating the overall situation of 3 events, it is concluded that political election has a significant impact on stock market. But the direction of relationship between them depends upon political conditions of the country. First two events have negative significance impact while third event showed positive significant impact. This study also supports the EMH hypothesis. Any news arising in the market is incorporated in stock prices. Favorable news creates positive impact and vice versa. It is required by the government to pay special attention towards the factors that contributes to the stability of political situation in the country. Future researchers could study the impact of Marshal Law on the economy of the country (Pakistan). Many other political events may also be included in the study. Moreover, cross country comparison of developed and developing countries situation during the general political election is also welcomed.

\section{References}

[1] Alesina, A., Spolaore, E., \& Wacziarg, R. (1997). Economic integration and political disintegration (No.w6163). National Bureau of Economic Research. https://doi.org/10.3386/w6163. 
[2] Election polls, free trade, and the stock market: evidence from the Canadian general election (No. w3073). National Bureau of Economic Research.

[3] Fama, E. F. (1965). The behavior of stock-market prices. The journal of Business, 38(1), 34-105. https://doi.org/10.1086/294743.

[4] Fong, W. M., \& Koh, S. K. (2002). The political economy of volatility dynamics in the Hong Kong stock market. Asia-Pacific financial markets, 9(3), 259-282. https://doi.org/10.1023/A:1024133632104.

[5] Floros, C. (2008). The influence of the political elections on the course of the Athens Stock Exchange 1996-2002. Managerial Finance, 34(7), 479-488. https://doi.org/10.1108/03074350810874433.

[6] Hibbs, D. A. (1977). Political parties and macroeconomic policy. American political science review, 71(04), 1467-1487. https://doi.org/10.2307/1961490.

[7] Huber, J., \& Kirchler, M. (2013). Corporate campaign contributions and abnormal stock returns after presidential elections. Public Choice, 156(1-2), 285-307. https://doi.org/10.1007/s11127-0119898-4.

[8] Jones, S., T., \& Banning, K. (2009). US elections and monthly stock market returns. Journal of Economics and Finance, 33(3), 273. https://doi.org/10.1007/s12197-008-9059-x.

[9] Khan, S., Baig, N., Usman, M., Shaique, M., \& Shaikh, R. Stock Market Dynamics in Pakistan: What Do Political Events and Budget Announcements Disclose?. Research Journal of Finance and Accounting 8(10)-113-123.

[10] Leblang, D., \& Mukherjee, B. (2005). Government partisanship, elections, and the stock market Examining American and British stock returns, 1930-2000. American Journal of Political Science, 49(4), 780-802. https://doi.org/10.1111/j.1540-5907.2005.00155.x.

[11] MacKinlay, A. C. (1997). Event studies in economics and finance. Journal of economic literature, 35(1), 13-39.

[12] Mishkin, F. S. (1982). Monetary Policy and Short-term Interest Rates: An Efficient Markets-Rational Expectations Approach. The Journal of Finance, 37(1), 63-72. https://doi.org/10.1111/j.15406261.1982.tb01095.x.

[13] Manning, D. N. (1989). The effect of political uncertainty on the stock market: the case of British Telecom. Applied Economics, 21(7), 881-890. https://doi.org/10.1080/758518229.

[14] Nippani, S., \& Arize, A. C. (2005). US presidential election impact on Canadian and Mexican stock markets. Journal of Economics and Finance, 29 (2), 271-279. https://doi.org/10.1007/BF02761558.

[15] Pepinsky, T. (2007). Autocracy, elections, and Fiscal policy: Evidence from Malaysia. Studies in Comparative International Development, 42(1-2), 136-163. https://doi.org/10.1007/s12116-0079006-4.

[16] Steeley, J. M. (2003). Making Political Capital: The behaviour of the UK capital markets during Election'97. Applied financial economics, 13(2), 85-95. https://doi.org/10.1080/09603100210100873.

[17] Shum, P. M. (1996). Stock market response to political uncertainty: evidence from the 1992 constitutional referendum. The Canadian Journal of Economics/Revue canadienne d'Economique, 29, S213S218. https://doi.org/10.2307/135990. 